\title{
TINJAUAN YURIDIS TERHADAP KEJAHATAN KESUSILAAN YANG DILAKUKAN TERHADAP PEREMPUAN
}

\author{
Oleh : \\ Putu Natih* \\ Abadi B Darmo * \\ Chairijah*
}

\begin{abstract}
ABSTRAK
Tujuan penulisan ini menjelaskan dan menganalisis pengaturan terhadap kejahatan kesusilaan yang dilakukan terhadap perempuan dalam Perundang-undangan Indonesia dan kendala dalam penegakan hukum tindak pidana kesusilaan. Hal ini dilatarbelakangi perempuan sudah sejak lama menjadi obyek pengebirian dan pelecehan hak-haknya mulai dari perempuan dewasa sampai perempuan yang tergolong di bawah umur (anak-anak). Kejahatan ini tidak hanya berlangsung di lingkungan perusahaan, perkantoran atau di tempat-tempat tertentu yang memberikan peluang manusia berlawanan jenis dapat saling berkomunikasi, namun juga dapat terjadi di lingkungan keluarga.
\end{abstract}

Kata Kunci: Kejahatan Kesusilaan, Perempuan

\section{A. Latar Belakang Masalah}

Berbagai upaya telah dilakukan guna menghilangkan tidak kejahatan dari permukaan bumi namun kejahatan tersebut tidak pernah sirna dari peradaban umat manusia. Kejahatan memang tidak dapat dihapuskan dari muka bumi, karena ia tumbuh dan berkembang sejalan dengan kebudayaan manusia dan dilakukan oleh manusia sebagai salah satu sub sistem pendukung peradaban meskipun kejahatan tidak dikehendaki kelahirannya oleh masyarakat namun selalu ia akan tumbuh dalam masyarakat sebab dilakukan oleh salah satu anggota masyarakat tersebut.

Meskipun pada hakekatnya kejahatan tidak mungkin dihilangkan dari muka bumi namun sebagai manusia yang dibekali dengan akal fikiran, kita tidak dapat berpangku tangan melihat berbagai kemungkaran yang terjadi.Kejahatan merupakan perbuatan anti sosial yang meresahkan masyarakat dalam melakukan interaksi dengan sesamanya dimana perbuatan tersebut mendapat tantangan dari pemerintah atau negara. Sedangkan secara yuridis kejahatan dapat dikatakan sebagai suatu perbuatan melawan hukum dimana sebagai

\footnotetext{
* Wiraswasta, Alumni Program Magister Ilmu Hukum Unbari.

* Pengajar Program Magister Ilmu Hukum Unbari.

* Pengajar Program Magister Ilmu Hukum Unbari.
} 
akibat dari perbuatan itu, pelaku dapat dikenakan sanksi sebagaimana termaktub dalam peraturan undang-undang yang dilanggar tersebut.

Dari berbagai tindak kejahatan yang meresahkan masyarakat sekaligus bertentangan dengan hukum, penulis tertarik untuk menganalisa salah satu bentuk kejahatan, dalam hal ini kejahatan kesusilaan. Kejahatan kesusilaan adalah kejahatan yang berhubungan dengan kesusilaan. Definisi singkat dan sederhana ini apabila dikaji lebih lanjut untuk mengetahui seberapa jauh ruang lingkupnya ternyata tidaklah mudah, karena pengertian dan batas-batas 'kesusilaan' itu cukup luas dan dapat berbeda-beda menurut pandangan dan nilai-nilai yang berlaku di dalam masyarakat. Terlebih pada dasarnya setiap tindak pidana (delik) mengandung didalamnya pelanggaran terhadap nilai-nilai kesusilaan, bahkan dapat dikatakan bahwa hukum itu sendiri pada hakikatnya merupakan nilai-nilai kesusilaan yang minimal (das Recht ist das ethische Minimum). ${ }^{1}$

Kejahatan Kesusilaan atau kejahatan seksual pada umumnya dialami oleh para wanita khususnya anak-anak yang masih muda (remaja).Kejadian ini timbul dalam masyarakat tanpa melihat stratifikasi sosial pelaku maupun korbannya.Kejahatan tersebut dapat timbul karena pengaruh lingkungan maupun latar belakang kejiwaan yang mempengaruhi tindak tanduk pelaku dimasa lalu maupun karena guncangan psikis spontanitas akibat adanya rangsangan seksual. ${ }^{2}$

Rangsangan seksual yang tidak terkendali inilah yang pada gilirannya melahirkan kejahatan kesusilaan khususnya kejahatan perkosaan. Tindak pidana ini dahulu hanya dilakukan oleh pihak lain terhadap wanita yang bukan keluarga dengan melakukan ancaman dan paksaan atau kekerasan. Tetapi dewasa ini tindak pidana tersebut tidak hanya dilakukan dengan ancaman kekerasantetapi telah mempergunakan berbagai zat kimia yang dapat menghilangkan kesadaran wanita sekaligus menimbulkan rangsangan seksual tanpa disadarinya.

Namun suatu hal yang sangat mengecewakan, justru kejahatan kesusilaan tersebut dilakukan oleh orang-orang yang dikenal baik oleh para korban (seductive rape) misalnya guru, dokter, teman dekat dan orang tua kandung. Mereka-mereka pelaku kejahatan adalah orang dewasa dan orang yang seharusnya memberikan perlindungan kepada para korban dari gangguan keamanan lingkungan maupun tanggung jawab pendidikan dimasa yang akan datang.

hal. 2

\footnotetext{
${ }^{1}$ Adami Chazawi, Tindak Pidana Mengenai Kesopanan, Raja Grafindo Persada, Jakarta, 2005,
}

${ }^{2}$ Gerson W. Bawengan, Pengantar Psikologi Kriminil, Pradnya Paramita, Jakarta 1977, hal.22. 
Kejahatan kesusilaan memiliki pengertian yang berbeda-beda lebih luas terhadap kesusilaan. Kejahatan kesusilaan diartikan sebagai suatu bentuk pelanggaran/kejahatan terhadap nilai susila (norma kesusilaan). Norma kesusilaan merupakan norma yang membimbing manusia untuk hidup sesuai dengan nilai kemanusiaannya atau kesempurnaan hidup (insan kami). ${ }^{3}$

Setiap kejahatan yang melanggar hak-hak dasar kehidupan manusia dinilai melanggar norma kesusilaan, misalnya membunuh, menganiaya dan kejahatan lainnya. Kejahatan terhadap kesusilaan diartikan lebih sempit yaitu pelanggaran/kejahatan terhadap nilai susila masyarakat (adat istiadat yang baik,sopan santun, kesopanan dan keadaban) dalam bidang seksual. Demikian juga pelecehan seksual yang diartikan sebagai perbuatan yang memandang rendah atau menghinakan atau mengabaikan hak orang lain dalam bidang seksual. Jadi bisa dikatakan bahwa cakupan kejahatan kesusilaan sebenarnya meliputi kejahatan terhadap kesusilaan.

Hukum pidana Indonesia tidak mengatur secara eksplisit tentang kejahatan kesusilaan, tetapi hanya mengatur tentang kejahatan terhadap kesusilaan sebagimana diatur dalam Bab XIV Buku II Pasal 281 sampai dengan Pasal 303 KUHP dan Buku III Bab VI Pasal 532 sampai dengan Pasal 547 KUHP. Bentuk kejahatan dan pelanggaran terhadap kesusilaan dalam KUHP adalah:

1. Perzinahan (Pasal 284);

2. Perkosaan (Pasal 285);

3. Persetubuhan dengan wanita di bawah umur (Pasal 286 sampai dengan 288);

4. Percabulan (Pasal 289 sampai dengan 294);

5. Penghubungan percabulan (Pasal 295 sd. 297, 298, 506)

6. Pencegahan dan pengguguran kehamilan (Pasal 299, 534, 535);

7. Tindak pidana terhadap kesopanan-kesusilaan (Pasal 281 sampai dengan 283,283 bis,532 sampai dengan 533).

8. Mabok dan penjualan minuman yang memabukkan (Pasal 300, 536 sampai dengan 536).

9. Eksploitasi anak untuk mengemis atau mengerjakan pekerjaan yangberbahaya (Pasal 301).

10. Penagniayaan, dan perlakuan yang berlebihan terhadap binatang (Pasal302, 540 sampai dengan 541).

${ }^{3}$ Murtadha Muthahari, Etika Seksual Dalam Islam, Lentera, Jakarta, 1982, hal. 45. 
11. Perjudian (Pasal 303, 542 sampai dengan sampai dengan 544).

12. Peramalan atau tafsir mimpi (Pasal 545).

13. Menjual atau membagikan jimat-jimat atau memakai jimat saat memberikan kesaksian atau benda yang memiliki kekuatan gaib atau mengajarkan kesaktian yang dipakai untuk melakukan perbuatan pidana (Pasal 546 sampai dengan 547).

Kejahatan kesusilaan atau moral offences merupakan dua bentuk pelanggaran atas kesusilaan yang bukan saja merupakan masalah hukum nasional suatu negara melainkan sudah merupakan masalah hukum semua negara di dunia atau merupakan masalah global. ${ }^{4}$ Pelaku kejahatan kesusilaan bukan dominasi mereka yang berasal dari golongan ekonomi menengah atau rendah apalagi kurang atau tidak berpendidikan sama sekali, melainkan pelakunya sudah menembus semua strata sosial dari strata terendah sampai tertinggi.

Di antara manusia Indonesia yang rawan menjadi korban kejahatan kekerasan adalah kaum perempuan. Beragam persoalan sensitif menimpa kehidupan kaum perempuan, antaranya kejahatan kekerasan seksual (sexual violence) dan pelecehan seksual (sexual harassment). Begitu banyak kejahatan kekerasan yang terjadi dan menimpa kaum perempuan, baik dalam soal pembunuhan, perkosaan, penganiayaan selain apa yang sudah disebutkan di atas. Perempuan sangat rentan menjadi korban kejahatan (victim of crime) di bidang kesusilaan.

Perempuan sedang menjadi obyek pengebirian dan pelecehan hakhaknya.Perempuan sedang tidak berdaya menghadapi kebiadaban individual, kultural dan struktural yang dibenarkan.Nilai-nilai kesusilaan yang seharusnya dijaga kesuciannya sedang dikoyak dan dinodai oleh naluri kebinatangan yang diberikan tempat untuk berlaku sebagai adidaya.Kekerasan, pelecehan, dan eksploitasi seksual, bukan hanya menimpa perempuan dewasa juga perempuan yang tergolong di bawah umur (anak-anak).Kejahatan seksual ini tidak hanya berlangsung di lingkungan perusahaan, perkantoran atau di tempattempat tertentu yang memberikan peluang manusia berlawanan jenis dapat saling berkomunikasi, namun juga dapat terjadi di lingkungan keluarga.

Kejahatan kesusilaan tidak muncul secara tiba-tiba, tetapi melalui proses pelecehan yang pada mulanya dianggap biasa, namun kemudian bermuara pada kejahatan. Pelecehan seks adalah penyalahgunaan hubungan perempuan dan laki-laki yang merugikan salah satu

${ }^{4}$ Romli Atmasasmita, Kapita Selekta Hukum Pidana dan Kriminologi, Mandar Maju, Bandung, 1995, hal. 103 . 
pihak (karena dilecehkan maka direndahkan martabatnya). Jadi pelecehan seks tidak hanya berupa pelecehan terhadap perempuan yang merendahkan martabat, namun juga dapat terjadi pada laki-laki, namun yang paling sering mengalami pelecehan seksual adalah perempuan.

\section{B. Perumusan Masalah}

Adapun pertanyaan-pertanyaan penelitian yang memfokuskan permasalahan di atas adalah:

1. Bagaimanakah pengaturan terhadap kejahatan kesusilaan yang dilakukan terhadap perempuan dalam Perundang-undangan Indonesia?

2. Bagaimanakahkendala dalam penegakan hukum tindak pidana kesusilaan?

\section{Metode Penelitian}

1. Tipe Penelitian

Mengacu pada perumusan masalah dan tujuan penelitian tersebut di atas, maka penelitian ini dilakukan dengan menggunakan penelitian yuridis normatif. Penelitian hukum normatif mencakup penelitian terhadap asas-asas hukum, sistematika hukum, sinkronisasi hukum, dan sejarah hukum. Penelitian normatif diambil sebagai pendekatan utama dalam penelitian ini karena yang menjadi perhatian utama adalah tinjauan yuridis terhadap kejahatan kesusilaan yang dilakukan orang dewasa terhadap remaja perempuan.

2. Spesifikasi Penelitian

Spesifikasi penelitian ini bersifat deskriptif analitis, dimana dalam penulisan ini bermaksud untuk memberikan gambaran dan uraian mengenai ketentuan perundang-undangan yang mengatur mengenai efektivitas norma penjatuhan pidana seumur hidup.

Data-data sekunder yang diperoleh dari hasil penelitian kepustakaan, kemudian dikumpulkan, disusun, diolah dan dipisah-pisahkan ke dalam bagianbagian tertentu, untuk seterusnya dianalisis.

Analisis yang digunakan dalam penelitian ini bersifat analisis kualitatif, yaitu dengan menelaah berbagai peraturan hukum yang berlaku, teori-teori pendapat ahli atau sarjana hukum yang kemudian dihubungkan dengan judul yang dibahas.

5. Penyajian Data 
Data-data yang telah dianalisis dan diolah menjadi suatu laporan hasil penelitian dan analisis secara tertulis dan tersusun secara sistematis, yang berisikan secara lengkap mengenai kegiatan penelitian yang dilakukan terbatas pada penelitian kepustakaan untuk mencari data sekunder saja, permasalahan serta pembahasan yang dikupas secara sistematik di dalam Bab IV tesis ini sebagai akhir dari kegiatan penelitian.

\section{Tinjauan Yuridis Terhadap Kejahatan Kesusilaan Yang Dilakukan Terhadap Perempuan}

1. Pengaturan Terhadap Kejahatan Kesusilaan Dalam Perundang-undangan Indonesia.

Dalam kehidupan sehari-hari banyak sekali kaum perempuan yang mengalami tindak kekerasan ini tanpa dapat berbuat banyak untuk menghindarinya dan terpaksa harus membiarkan hal ini terjadi. Sebelum naik angkutan kota misalnya, seorang perempuan terpaksa adu mulut dengan kondektur angkutan kota yang meraba pantatnya dengan alasan membantunya naik angkot, meski si perempuan tidak memerlukan hal ini sama sekali. Hanya beberapa menit ia duduk di bangku yang tersedia ia harus menggeser posisi duduknya dengan muka merah menahan marah karena seorang laki-laki yang menggesekkan bagian depan tubuhnya (yang terletak di bawah pinggang) ke pundak perempuan tersebut.

Kejahatan kesusilaan memiliki pengertian yang berbeda-beda lebih luas terhadap kesusilaan dan pelecehan seksual. Kejahatan kesusilaan diartikan sebagai suatu bentuk pelanggaran/kejahatan terhadap nilai susila (norma kesusilaan).Norma kesusilaan merupakan norma yang membimbing manusia untuk hidup sesuai dengan nilai kemanusiaannya atau kesempurnaan hidup. Setiap kejahatan yang melanggar hak-hak dasar kehidupan manusia dinilai melanggar norma kesusilaan, misalnya membunuh, menganiaya dan kejahatan lainnya.

Contoh lain pelecehan seksual yang dialami oleh kaum perempuan ditempat umum seperti terminal, tempat rekreasi, tempat perbelanjaan dansebagainya, maka hal yang sama yang dihadapi perempuan lain di tempat kerjamerupakan masalah tersendiri bagi perempuan yang bersangkutan. Bilaperempuan yang mendapat pelecehan seksual di tempat umum masih memilikikesempatan untuk menghindar maka tidak demikian halnya untuk perempuanyang mengalaminya di tempat kerja.Mereka tidak hanya dihadapkan padapersoalan fisik dan emosional semata tetapi juga persoalan ekonomi dandihadapkan 
pada sejumlah resiko seperti kehilangan pekerjaan, kehilangankesempatan untuk promosi jabatan, kehilangan kesempatan untuk naik gaji, danlain-lain jika mereka menolak godaan seksual yang dilancarkan oleh atasannya.

Misalnya, seorang buruh perempuan dengan berat hati terpaksa membiarkan bagiantubuhnya digerayangi Satpam di pabrik saat ia melewati pintu kecil di depan pospenjagaan sebelum memasuki pabrik. Atau seorang perempuan yang bekerjasebagai staf administrasi terpaksa duduk kaku di kursinya setiap atasanmenyentuh pipinya pada saat memberikan surat-surat untuk diketik misalnya.

Seperti telah disebutkan sebelumnya bahwa pelecehan seksual dapat mengenai perempuan dari berbagai golongan usia dan kelas sosial, begitupun dengan pelakunya. Namun seringkali orang keliru menganggap persoalan ini hanya mengenai dan dilakukan oleh mereka yang berada di kelas sosial ekonomi bawah.Kenyataan yang ada adalah bahwa segala bentuk tindak kekerasan terhadap perempuan yang terjadi di kelas menengah atas sangat sulit untuk dibuktikan karena rapatnya dinding-dinding yang membatasi kelompok ini.

Contoh lain maraknya kejahatan kesusilaan dewasa ini berkenaan dengan "Behaviour in relation sexual matter" biasanya berbentuk pencabulan baik yang dilakukan oleh sepasang orang dewasa atau sesama orang dewasa maupun dengan anak dibawah umur. Pelaku kejahatan tersebut merasa bahwa anak-anak dapat menjadi salah satu sasaran untuk menyalurkan hasrat seksualnya. Hal ini dipengaruhi oleh pendapat bahwa anak-anak tidak cukup mampu untuk mengerti bahwa perbuatan itu merupakan tindak pidana atau anak-anak tidak mempunyai keberanian untuk menolak keinginan pelaku.

Kekerasan seksual yang dilakukan terhadap anak di bawah umur tentunya akan berdampak pada psikologis maupun perkembangan lainnya terhadap anak tersebut. Dampak psikologis pada anak-anak akan melahirkan trauma berkepanjangan yang kemudian dapat melahirkan sikap tidak sehat, seperti minder, takut yang berlebihan, perkembangan jiwa terganggu, dan akhirnya berakibat pada keterbelakangan mental. Keadaan tersebut kemungkinan dapat menjadi suatu kenangan buruk bagi anak korban pencabulan tersebut. Peran aktif dari para aparat penegak hukum dalam menanggulangi kejahatan kesusilaan sangat diperlukan.

Kejahatan terhadap kesusilaan diartikan lebih sempit yaitu pelanggaran/kejahatan terhadap nilai susila masyarakat (adat istiadat yang baik,sopan santun, kesopanan dan keadaban) dalam bidang seksual. Demikian juga pelecehan seksual yang diartikan sebagai 
perbuatan yang memandang rendah atau menghinakan atau mengabaikan hak orang lain dalam bidang seksual. Jadi bisa dikatakan bahwa cakupan kejahatan kesusilaan sebenarnya meliputi kejahatan terhadap kesusilaan dan pelecehan seksual.

Hukum pidana Indonesia tidak mengatur secara eksplisit tentang kejahatan kesusilaan dan pelecehan seksual, tetapi hanya mengatur tentang kejahatan terhadap kesusilaan sebagimana diatur dalam Bab XIV Buku II Pasal 281 sampai dengan Pasal 303 KUHP dan Buku III Bab VI Pasal 532 sampai dengan Pasal 547 KUHP. Bentuk kejahatan dan pelanggaran terhadap kesusilaan dalam KUHP dapat dideKarya Ilmiahkan :

1. Perzinahan (Pasal 284);

2. Perkosaan (Pasal 285);

3. Persetubuhan dengan wanita di bawah umur (Pasal 286 sd 288);

4. Percabulan (Pasal 289 sd. 294);

5. Penghubungan percabulan (Pasal 295 sd. 297, 298, 506)

6. Pencegahan dan pengguguran kehamilan (Pasal 299, 534, 535);

7. Tindak pidana terhadap kesopanan-kesusilaan (Pasal 281 sd. 283,283 bis, 532 sd. 533).

8. Mabok dan penjualan minuman yang memabukkan (Pasal 300, 536 sd. 536).

9. Eksploitasi anak untuk mengemis atau mengerjakan pekerjaan yang berbahaya (Pasal 301).

10.Penagniayaan, dan perlakuan yang berlebihan terhadap binatang (Pasal 302, 540 sd. 541).

11. Perjudian (Pasal 303, 542 sd. 544).

12. Peramalan atau tafsir mimpi (Pasal 545).

13. Menjual atau membagikan jimat-jimat atau memakai jimat saat memberikan kesaksian atau benda yang memiliki kekuatan gaib atau mengajarkan kesaktian yang dipakai untuk melakukan perbuatan pidana (Pasal 546 sd. 547).

Jika dikaitkan dengan konsep perumusan diatas, ternyata konsep KUHP meliputi pengertian kesusilaan tidak hanya dibidang seksual saja melainkan juga meliputi perbuatan mabok, perjudian, tindakan berlebihan terhadap hewan, eksploitasi anak, peramalan dan jimat atau kekuatan ghaib. Kendatipun tidak secara eksplisit, perbuatan pelecehan seksual dapat dimasukkan dalam ketentuan Pasal 281 sampai dengan Pasal 283 KUHP.Sistematika perumusan Kitab Undang-Undang Hukum Pidana (KUHP) mengenai kejahatan terhadap 
kesusilaan tersebut kurang jelas maksudnya, apakah pengertiannya secara luas atau sempit?Sedangkan Naskah Rancangan KUHP (Baru) masih tetap menggunakan sistematika KUHP (lama), memasukkan mabuk, eksploitasi anak untuk mengemis atau mengerjakan pekerjaan yang berbahaya, perlakuan berlebihan terhadap binatang, dan perjudian.Sistematika perumusan seperti ini sebaiknya diubah. KUHP yang akan datang perlu ada penegasan mengenai batasan kesusilaan terbatas pada bidang kesusilaan dalam arti seksual.Sehingga sistematika bab tentang kejahatan terhadap kesusilaan semakin jelas maksud/tujuan dan nilai filosofis dan kepentingan hukum yang hendak dilindungi oleh hukum pidana.

Permasalahan yang muncul adalah apakah yang menjadi ukuran bahwa suatu perbuatan itu melanggar kesusilaan?Tolok ukur mengenai kesusilaan ini perlu diberikan agar supaya peraturan hukum pidana mudah dipahami bukan saja oleh penegak hukum tetapi juga oleh masyarakat pada umumnya.Karena persoalan kesusilaan berkaitan dengan nilai dan pandangan hidup suatu bangsa, maka sebaiknya nilai kesusilaan itu bersendikan pada nilai moral dan agama yang dianut oleh bangsa Indonesia.

Nilai moral dan agama yang dianut di Indonesia tersebut memiliki perpautan dengan pandangan hidup bangsa Indonesia yaitu Pancasila sekaligus menjadi dasar yang kokoh dalam pembentukan moral bangsa Indonesia khususnya di bidang kesusilaan. Jika demikian halnya, maka ada beberapa perbuatan yang dipandang perlu untuk ditetapkan sebagai perbuatan yang dilarang dalam hukum pidana yaitu:

1. Persetubuhan di luar ikatan pernikahan (zina) yaitu persetubuhan antara seorang pria dan wanita dewasa yang keduanya tidak dalam ikatan pernikahan dan bersifat mau sama mau.

2. Pergundikan / selir.

3. Pelacuran (prostitution)

4. Homoseks (sodomia sexus) dan lesbian

5. Persetubuhan dengan binatang (sodomia grneris)

6. Percabulan antara sesama jenis atau lain jenis yang keduanya sudahdewasa dan mau sama mau.

7. Dan bentuk penyimpangan seksual lainnya.

Sebagaimana dikemukakan diatas, bahwa segalabentuk kejahatan terhadap kesusilaan dipengaruhi oleh persepsi terhadap seksual,maka bagi bangsa Indonesia yang mengagungkan institusi perkawinan perumusankejahatan terhadap kesusilaan dalam 
KUHP memiliki arti fungsional dalammenjaga kesucian dan keagungan institusi perkawinan.Sebagai konsekuensinya,segala bentuk perbuatan yang menimbulkan akibat merosotnya nilai moral ataususila masyarakat sudah semestinya dilarang dalam hukum pidana. Lebih dariitu, prinsip ini dijadikan dasar pengambilan keputusan dalam bidang sosial danpublik, misalnya, pers, media audo visual, dan kebijakan lainnya, sehingga hukumpidana sebagai "ultimum remedium" menjadi benar-benar berarti.

Sungguh ironis, KUHP yang sekarang diberlakukan tidak melarang delikgenus dari delik-delik terhadap kesusilaan - hubungan seksual di luar ikatanpernikahan yang di lakukan oleh laki-laki dan wanita atas dasar suka sama suka,sementara kejahatan lain yang menuju kearah itu atau yang menyimpang dari nilaikesusilaan menjadi dilarang.

Kenyataannya saat ini upaya penerapan hukuman bagi pelaku tindak pidana kesusilaan tersebut belum dapatdiberikan secara maksimal oleh pemerintah, aparat penegak hukum,masyarakat dan pihak-pihak lain yang berhak membantu.Keadilan yangdiberikan oleh penerapan hukum melalui penjatuhan sanksi hukum yangdijatuhkan pada pelaku tidak adil atau tidak sesuai dengan akibat yangditimbulkannya.Ketidakadilan hukum inilah yang disebut-sebut dapatmenjauhkan masyarakat yang tertimpa musibah (menjadi korban suatukejahatan) untuk bersedia berurusan dengan dunia peradilan.

Dari segi pemerintah, upaya yang belum dapat diberikan secara maksimal adalah kurangnya partisipasi dan sosialisasi tentang bahayanya kejahatan yang diakibatkan oleh tindak pidana kesusilaan ini.dan diharapkan dengan sosialisasi tersebut masyarakat jangan takut akan melaporkan kejadian yang menimpa mereka terkait dengan tindak pidana kesusilaan. Kemudian upaya yang belum diberikan secara maksimal oleh aparat penegak hukum dapat dilihat dari putusan yang dipakai untuk mengadili pelaku dipandang tidak relevan untuk memberikan efek jera bagi si pelaku.

2. Kendala-kendala dalam Penegakan Hukum dalam Tindak Pidana Kesusilaan.

Ditemukan beberapa kelemahan yuridis yang dimiliki KUHP, yaitu:

1. Pasal-pasal kesusilaan dalam KUHP tersebut tidak memuat mengenai batasanbatasan perbuatan sehingga dikategorikan melanggar kesusilaan aanstoteljk van de eerbaarheid. Sedangkan istilah melanggar kesusilaan atau aanstotelijk van de eerbaarheid yang dipakai KUHP ternyata sangat relatif yang tergantung pada ruang dan waktu dan secara subyektif dapat menimbulkan berbagai 
macam penafsiran.Misalnya pemahaman mengenai model pakaian di pedalaman Papua tidak dapat begitu saja disamakan dengan pemahaman di masyarakat Aceh.Hal ini berarti ada aspek mengenai batasan kesusilaan yang belum diselesaikan.Kelemahan secara yuridis ini berimbas pada lemahnya penegakan hukum law enforcement atas tindak pidana kesusilaan ini.

2. Ancaman pidana bagi para pelanggar tindak pidana ini sangatlah lemah, terutama pidana dendanya. Kelemahan ini dimiliki oleh KUHP secara umum, mengingat KUHP yang aslinya bemama Wetboek van Strafrecht ini dibuat pada masa kolonial Belanda.

3. Subyek hukum yang dikenal dalam KUHP adalah perorangan. Artinya, yang dapat diancam dengan sanksi pidana adalah manusia alamiah.Sedangkan subyek hukum berupa badan hukum rechtpersoon belum dikenal dalam KUHP. Sedangkan kendala-kendala yang dihadapi oleh aparat penegak hukum dalam melakukan penegakan hukum diantaranya adalah:

1. Adanya penafsiran yang berbeda-beda terhadap kesusilaan.

Kendatipun bersumber dari peraturan hukum yang sama. Nilai kesusilaan sering ditafsirkan secara relatif, karena mendasarkan pandangannya pada nilai susila masyarakat dari sudut pandang sosiologis.

2. Persoalan delik kesusilaan sebagai delik aduan.

Perumusan kejahatan delik kesusilaan sebagai delik aduan dapat dijadikan kendala dalam penegakan hukum di bidang kesusilaan.

3. Persoalan pembuktian.

Memang diakui bahwa pembuktian delik terhadap kesusilaan termasuk delik yang sulit proses pembuktiannya. Tidaklah bijaksana jika sulitnya pembuktian dijadikan alasan untuk tidak melarang perbuatan perzinahan dan perbuatan lainnya di bidang kesusilaan.

4. Kedudukan perempuan dalammasyarakat.

Kedudukan perempuan pada umumnya berada dalam posisitersubordinasi secara kultural dan diterima secara universal.

5. Moral aparat penegak hukum.

Bagaimanapun kejahatan terhadapkesusilaan dan pelecehan seksual adalah bentuk kejahatan yang bukansemata-mata pelanggaran terhadap aturan hukum pidana saja melainkandi dalamnya terkait dengan nilai kesusilaan (moral) yang 
hendakditegakkan.Kualitas moral aparat penegak hukum ikut menentukankualitas produk hukum yang ditegakkan.

6. Terjadi pergeseran nilaidalam masyarakat dengan intensitas yang cukup tinggi yang dipertajamdengan pola kebijakan yang tidak terkoordinasi khususnya yang berkaitandengan perlindungan terhadap kesusilaan.

Kasus tindak pidana kesusilaan paling banyak menimbulkan kesulitan dalam penyelesaiannya baik pada tahap penyidikan, penuntutan, maupun pada tahap penjatuhan putusan. Selain kesulitan dalam batasan di atas, juga kesulitan pembuktian misalnya perkosaan atau perbuatan cabul yang umumnya dilakukan tanpa kehadiran orang lain

Alasan kasus-kasus tindak pidana kesusilaan ini tidak dilaporkan oleh korban kepada aparat penegak hukum untuk diproses ke Pengadilan karena beberapa faktor, diantaranya korban merasa malu dan tidak ingin aib yang menimpa dirinya diketahui oleh orang lain, atau korban merasa takut karena telah diancam oleh pelaku bahwa dirinya akan dibunuh jika melaporkan kejadian tersebut kepada polisi. Hal ini tentu saja mempengaruhi perkembangan mental/kejiwaan dari para korban dan juga berpengaruh pada proses penegakan hukum itu sendiri untuk mewujudkan rasa keadilan bagi korban dan masyarakat.

Faktor korban berperan penting untuk dapat mengatasi atau menyelesaikan kasus tindak pidana kesusilaan ini, hal ini memerlukan keberanian dari korban untuk melaporkan kejadian yang menimpanya kepada polisi, karena pada umumnya korban mengalami ancaman oleh pelaku dan hal ini membuat korban takut dan trauma. Diharapkan dari pengaduan ini, maka kasusnya dapat terbuka dan dapat dilakukan proses pemeriksaan sehingga korban akan memperoleh keadilan atas apa yang menimpa dirinya.

Selanjutnya upaya yang dilakukan adalah:

1. Upaya Preventif

Upaya ini dilakukan untuk mencegah, menghindarkan seseorang untuk tidak melakukan tindak pidana kesusilaan.Adapun upaya preventif tersebut adalah melakukan penyuluhan-penyuluhan tentang dampak negatif dari tindak pidana kesusilaan.Penyuluhan ini agar seluruh lapisan masyarakat turut berpartisipasi dalam upaya penanggulangan tindak pidana kesusilaan secara bersama-sama dan terpadu.Pihak-pihak yang menjadi sasaran penyuluhan adalah pelajar, mahasiswa, elemen pemuda, tokoh agama dan masyarakat.

2. Upaya Represif 
Upaya ini dilakukan setelah terjadinya peristiwa tindak pidana kesusilaan, dilakukan dengan cara melakukan penangkapan, pemeriksaan sampai melakukan penuntutan dan penghukuman bagi pelaku tindak pidana kesusilaan.

\section{E. Kesimpulan}

1. Pengaturan tentang tindak pidana kesusilaan dalam Hukum pidana Indonesia tidak mengatur secara eksplisit tentang kejahatan kesusilaan dan pelecehan seksual, tetapi hanya mengatur tentang kejahatan terhadap kesusilaan sebagimana diatur dalam Bab XIV Buku II Pasal 281 sampai dengan Pasal 303 KUHP dan Buku III Bab VI Pasal 532 sampai dengan Pasal 547 KUHP. Dalam penerapan hukumnya sudah berjalan namun belum optimal. upaya yang belum diberikan secara maksimal oleh aparat penegak hukum dapat dilihat dari putusan yang dipakai untuk mengadili pelaku dipandang tidak relevan untuk memberikan efek jera bagi si pelaku.

2. Kendala dalam penegakan hukum tindak pidana kesusilaan ini antara lain adanya penafsiran yang berbeda-beda terhadap kesusilaan, persoalan delik kesusilaan sebagai delik aduan, persoalan pembuktian, kedudukan perempuan dalam masyarakat, moral aparat penegak hukum, terjadi pergeseran nilai dalam masyarakat dengan intensitas yang cukup tinggi yang dipertajam dengan pola kebijakan yang tidak terkoordinasi khususnya yang berkaitan dengan perlindungan terhadap kesusilaan. Terhadap kendala tersebut telah dilakukan upaya-upaya untuk mengatasinya yaitu dengan melakukan penyuluhan-penyuluhan kepada masyarakat, tokoh agama, pelajar, mahasiswa dan elemen pemuda. Selain itu dilakukan upaya penindakan secara hukum pidana melalui sistem peradilan pidana terpadu.

\section{E. Rekomendasi}

1. Agar penegakan hukum bagi pelaku tindak pidana maka penerapan konsepsi keadilan harus benar-benar dapat diwujudkan, demi terlindunginya hak dan masa depan korban tindak pidana kesusilaan, maka kepada pihak yang berkompeten terhadap program legislasi nasional, direkomendasikan untuk segera melakukan 
pembaharuan KUHP dan KUHAP, dan melakukan revisi ketentuan pidana di dalam Undang-Undang lex specialis terkait.

2. Agar korban, keluarga korban dan masyarakat dapat melaporkan kejadian yang menimpa dirinya, keluarganya kepada aparat penegak hukum terkait kasus tindak pidana kesusilaan yang menimpanya. Dengan demikian akan mengurangi peristiwa tindak pidana kesusilaan yang terjadi di tengah masyarakat. Melakukan sosialisasi berupa penyuluhan hukum terpadu sehingga masyarakat dapat menjaga dirinya dan keluarganya dari perbuatan tindak pidana kesusilaan.

\section{F. Daftar Pustaka}

Adami Chazawi, Tindak Pidana Mengenai Kesopanan, Raja Grafindo Persada, Jakarta, 2005

Gerson W. Bawengan , Pengantar Psikologi Kriminil, Pradnya Paramita, Jakarta 1977

Murtadha Muthahari, Etika Seksual Dalam Islam, Lentera, Jakarta, 1982

Romli Atmasasmita, Kapita Selekta Hukum Pidana dan Kriminologi, Mandar Maju, Bandung, 1995 